\title{
Current Problems of Water Supply and Usage in Central Asia, Tian Shan Basin
}

\author{
Polina Lemenkova, Charles University
}

\begin{abstract}
The paper focuses on analysis of Central Asian hydroenergetic system and water usage in Tian Shan region. Tian Shan system is an important water resource in Central Asia: river waters are intensely taken for hydropower energy, urban systems, irrigation. But geopolitics in Tian Shan is difficult: it crosses five densely populated countries. The problem consists in water delivery between countries located in the highlands with excellent water supply (Tajikistan and Kyrgyzstan) and those located in valleys with water shortage (Kazakhstan and Uzbekistan). The water use causes debates among these countries. Besides, global warming causes water deficit, which adds difficulties to hydroenergetics. A multidisciplinary analysis was performed in the article: water supply in Tian Shan, spatial distribution of hydroenergetic resources and effects of climate impact were analyzed.
\end{abstract}

Keywords - hydro energy, renewable resources, Tan Shan, water usage.

\section{INTRODUCTION}

The paper focuses on environmental analysis of Central Asian energetic system and usage of waters from Tian Shan glaciers. The Tian Shan is a Central Asian mountain system extending to $2,500 \mathrm{~km}$ breadthwise. It is one of the major water supplies in Central Asia, since it contains 7,590 glaciers with an overall area of $13,271.45 \mathrm{~km}^{2}$. Many rivers originate in these glaciers and snowfields and feed major river streams. Intensely taken for hydropower energy production, sustainable functioning of urban systems, agricultural activities, irrigation and other human needs, river waters are highly important hydrological resource for local population. At the same time, Tian Shan has a critical geopolitical position because it crosses five densely populated Central Asian countries. Therefore, actual problem of water usage system in the region consists of water delivery pattern.

Tian Shan region can be divided on territories located in the highlands of plateaux with rich hydrological resources and excellent water supply, and region with water shortage, located in the lowlands and valleys. For example, Tajikistan and Kyrgyzstan control basins of Syrdaria and Amudaria rivers, while Kazakhstan and Uzbekistan are dependent on water delivery. Nowadays, the problem of water supply is a subject of discussions and conflicts among neighboring countries in Tian Shan region.

Apart from geographic location, there are impacts of environmental and climate change on water resources. Global warming seriously affects Tian Shan hydrological system and causes glacier reduction, decrease of snow coverage in high mountains, and deficit of waters. Multiplied by geopolitical questions, this leads to difficulties in water supply and usage. A multidisciplinary analysis was performed in the current work: geopolitical problems of water supply in Tian Shan caused by regional distribution of hydropower resources, and impact of climate change on the hydrological settings within study area.

\section{GEOGRAPHIC SETtings OF TIAN SHAN REgION}

\section{A. Geographic location of the study area}

The Tian Shan is a Central Asian complex mountain system extending in a westward direction (Fig.1). Geographically, Tian Shan straddles five countries with population mostly supporting traditional style of life which includes livestock husbandry, intense grazing, farming and other agricultural activities. Tian Shan is the northernmost existing montane range with elevations of peaks reaching higher than $7.000 \mathrm{~m}$. Environmental settings of Tian Shan are influenced by a combination of Northern (boreal) and Asian climatic factors. Therefore, Tian Shan has a unique and diverse mountainous environment, with more than 4000 wild species, many of which are endemic, rare and relict.

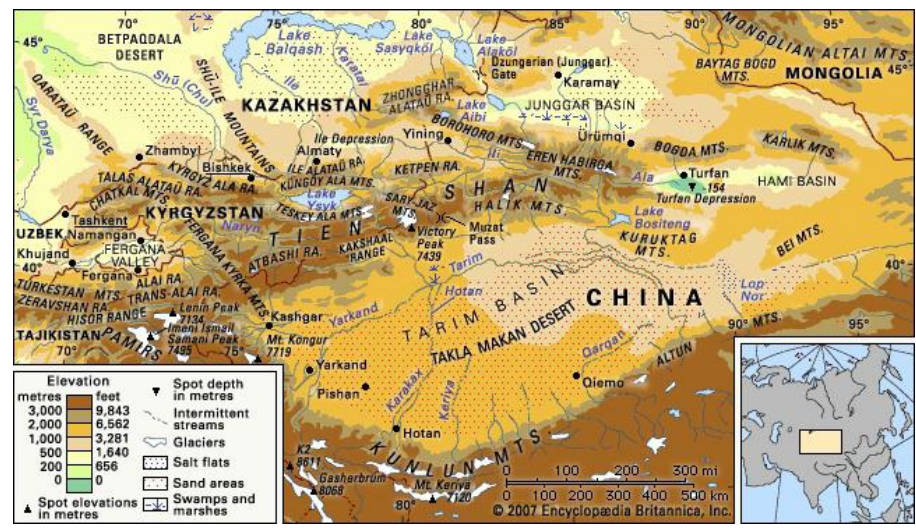

Fig. 1. Study region: Tian Shan mountains, Central Asia. Source: Britannica Encyclopedia.

The Tian Shan (sometimes referred as Tien Shan), or Celestial Mountains, is one of the largest high mountain systems in continental climate of Central Asia, covering $800000 \mathrm{~km}^{2}$. Geographically, Tian Shan extends $2,500 \mathrm{~km}$ westwards across Central Asia between $39^{\circ}-46^{\circ} \mathrm{N}$ and $69^{\circ}-95^{\circ}$ E. The Tian Shan ranges compose large, isolated montane system, surrounded by the Tarim desert basin of north-western China, Lake Issyk Kul, and north-western desert regions in Uzbekistan and Kazakhstan. The altitude belt of the mountain range lies between the 2,800 and 7,400 m with most major peaks located at 4000-6000 m, and the highest altitude reaching 7,349 $\mathrm{m}$ [18].

\section{B. Environment of Tian Shan: current issues}

Since the mid-1970s the observation of the remotely located areas of the Earth has been facilitated due to the development of 
the satellite industry, which provided remote sensing data for glacier monitoring. Systematic monitoring of the mountainous areas enabled to detect rapid changes in the glacier coverage of Tian Shan since past four decades. According to the numerous reports [2], [3], [6], [8], [10], there are changes in the current glaciation in Tian Shan mountains, which causes changes in hydro-energetic resource supply. There are twofold reasons for the environmental and hydrological changes in this area, caused by climate reasons and by the anthropogenic factors. These factors are discussed below.

Impact of climate on hydro resources: The main reason for the deglaciation is overall increase of summer temperatures and precipitation, which are the consequences of climate change. Thus, the average rise in air temperature in Tian Shan mountains is $0.01^{\circ} \mathrm{C} \mathrm{yr}$ over the range, and the precipitation in the Tien Shan increased to $1.2 \mathrm{~mm}$ yr since the 1950s [1]. Due to the geographical diversity of Tian Shan, there are certain variations in the temporal changes of environmental parameter, such as surface air temperature, precipitation, runoff, glacier mass, and snow thickness. Hence, the precipitation increase is lesser at high altitudes at above 2000. The low altitudes in northern and western regions are mostly affected by climate change comparing to inner and southern regions [1]. Recently increased in air temperatures in Tian Shan reinforced thawing of the glaciers, the period and intensity of melt.

However, due to the strong impact of the geographic location and local climate factors, glaciers in different regions of Tian Shan melt with different rates. The most intensive glacier retreat is detected on the northern ranges of Tian Shan: $-361 \mathrm{~km}^{2}$, which constitutes $14,3 \%$ [18], while the southern areas are the least affected. Also high rates in melt are detected in the central and inner areas: 287 and $244 \mathrm{~km}^{2}$ with $10 \%$ and 5\% respectively [18]. Climate change has also affected hydrological systems of semi-desert area of Aral Sea, which in turn are affecting seasonal water availability for irrigation in the Aral Sea. Thus, it is reported [15] that recently the summer floods, which is necessary for irrigation in Uzbekistan is reduced in the last decades. Water shortage necessarily affecting hydro-economic sectors of the countries located in the disaster area, such as Uzbekistan and Kazakhstan.

Impact of anthropogenic factors: Possible anthropogenic threats, that can induce environmental changes, include overgrazing at higher elevations by the local people, and local deforestation, which may lead to the partial decrease in biodiversity of the Tian Shan. Finally, the work of forest management and guarding has been weakened in the last years. As a result of cattle overgrazing, fires, deforestation, terracing of slopes, assignment of the grounds under construction of various objects and other factors, there is an essential reduction of an area of distribution of wood and tangled vegetation.

Due to the environmental threats and increased anthropogenic pressure on such fragile environment, the environment of Tian Shan will degrade: for example, the mountain forest area would decrease by $10-20 \%$ with 50 years. Another problem is connected to Aral Sea: due to the salinization and drying of the Aral Sea in Central Asia, which is a part of Tian Shan basin, the large areas of saline soil have now formed. Additionally, monsoon winds carry over towards south direction of Tajikistan and Kyrgyzstan, naturally contribute to the intensive melting of glaciers. It is demonstrated [5] that the Aral Sea basin has suffered an enormous shortage of water resources during the last decades. The consequences of drying lakes and rivers have extremely negative effects on the society, economic sector and hydro energy supply. The human-controlled hydrological regime of the major tributary rivers, Amu Daria and Syr Daria, flowing into Aral Sea, is a major factor affecting ecosystem sustainability, which are especially sensitive in the conditions of the semi-arid climate of Aral Sea Basin [17].

\section{HYDRO-ENERGETIC RESOURCES OF TIAN SHAN}

\section{A. Glaciation of Tian Shan}

The general hydrologic settings and distribution of glaciers in Tian Shan are largely influenced by the climatic factors and geographic location in Central Asia. The annual air temperatures affect precipitation regime of Tian Shan: runoff, snow and ice coverage. Totally, there are 7,590 glaciers with an overall area of $13,271.45 \mathrm{~km}^{2}$ detected in Tian Shan [18], which makes it one of the major water supply in Central Asia. The most prevalent glacier type is large valley glacier, which takes $82 \%$ of all glacier areas [18]. Glaciers often occur along the crests of the mountain ranges. The largest glaciers are concentrated in the central, inner part of Tian Shan. Since the Late Pleistocene Maximum, there are fluctuations in Tian Shan glaciation with the maximum level corresponding to the Issyk-Kul lake transgression [8]. The changes in the glaciation regime are still presented, which includes a general trend of warming, but also some advances of small glaciers occurred recurrently, as proved by moraine sediments [8].

\section{B. Hydrology and climate of Tian Shan}

The rivers in Tian Shan have typically mountainous character, since there is a significant difference in elevations between the mountain ridges and the plains at their base, river streams, usually plunge down the mountain slopes through deep and narrow gorges (Fig.2). After they flow out onto the plains, they form vast fan-shaped deposits of silt and mud. Climatic conditions of Tian Shan directly affect hydro-energetic resources and influence formation of glaciers and snowfields. In general, Tian Shan has typical continental climate, which is caused by Central Asian location. However, there are some local climatic differences formed in various geographic conditions: the most extremely cold and dry climate is in inner parts of mountains on the high plateaux, while northern and western slopes of Tien-Shan are characterized by more temperate climate. Thus, the mean summer temperature is $3.7^{\circ} \mathrm{C}$ at the altitude of the Equilibrium Line Altitude (ELA) in the western regions and $-8.1^{\circ} \mathrm{C}$ in the east; the annual precipitation is $1500-2000 \mathrm{~mm}$ in the west and $200-400 \mathrm{~mm}$ in the east, respectively. [8]. The northern slopes of Tian Shan, such as Kyrgyz Alatau and Zailinsky Alatau, have major influence of cyclonic activity. Precipitation in Tian Shan reaches its maximal level in spring and summer seasons, which coincides with the 
ice and snow melt. In winter the Siberian anticyclone prevents much precipitation in this area [3].

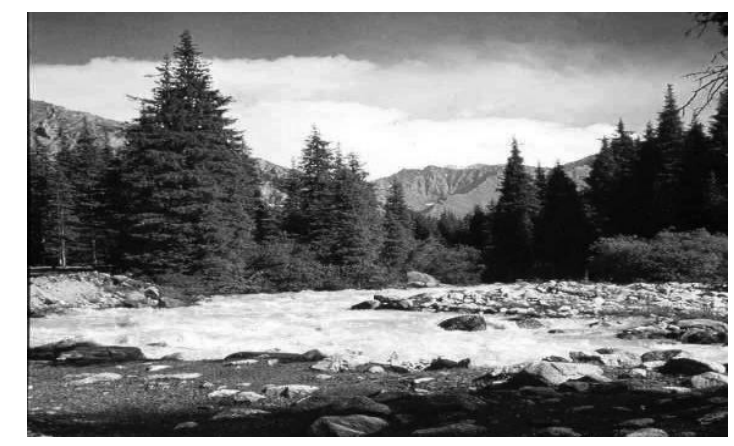

Fig. 2. Typical mountain river in Tian Shan. Source: ecosystema.ru

In general, the precipitation also increases with altitude. According to the moisture conditions, i.e. precipitation and evaporation, the alpine zone in Tian Shan ranges is similar to the zonal ecosystems of other mountain vegetation alpine zones in boreal and subboreal palearctic regions.

\section{WATER USAGE AND SUPPLY IN TIAN SHAN REGION}

Geopolitically, Tian Shan crosses borders of several Central Asian countries and western China. Approximately half of the Tian Shan mountains, the Eastern region from $80^{\circ} \mathrm{E}$ (eastwards from Issyk Kul Lake), is located in China, Xinjiang Uyghur Autonomous Region. Western territories are situated in Kyrgyzstan (including Issyk Kul lake depression), and northern ranges of Tian Shan are located in Kazakhstan. Some small ranges of the Tian Shan spread to Uzbekistan and Tajikistan.

\section{A. Hydro-energetic system in the region}

Hydropower resources are a major factor directly affecting and influencing sustainable development of the political and economic systems in Central Asia. The main water resources in Central Asia are located in Tajikistan and Kyrgyzstan, which control major river basins. It is caused by the upper location on Tian Shan plateau of both of these countries. For example, on the territory of Tajikistan $64 \mathrm{~km}^{3}$ of water flow of the Aral Sea basin is formed, which is ca $60 \%$ of the total flow towards Aral Sea basin [19]. The particularity of Tajikistan consists in hydroenergetic sector as the most powerful and influencing the overall economy of the country: $95 \%$ from all energetic sectors is taken by hydro-energy, while usually this part is not exceeding 10-20 $\%$ in other countries [14]. At the same time, only about $10 \%$ is used for internal purposes within the republic from the total country runoff. The rest of the runoff goes downwards from the country where it is used e.g. for irrigation. In Kazakhstan, on the contrary, it is demonstrated [4] that electricity demand in the country is high for all sectors: the industrial, service, and residential sectors, but the country depends on water resources. As for Kyrgyzstan, this country is rich in hydro energetic resources, and generates ca $90 \%$ of its electricity from largescale hydroelectric power stations, located along the cascade of the Naryn River. However, after the fall of the USSR, water resources in Kyrgyzstan have declined due to climate change issues, ineffective management and cross-border water claims among Central Asian states [13].

\section{B. Problem of water supply and usage: regional conflicts and decisions}

The reason of the hydro-energetic problems and water usage in Central Asia lies in the fact that water resources in Central Asia are unevenly distributed: Central Asian region is clearly divided into water-rich countries (Tajikistan and Kyrgyzstan) and those dependent on them (Uzbekistan, Turkmenistan and Kazakhstan). Kyrgyzstan majorly controls Syr Darya River basin, and Tajikistan - the Amu Darya river (Table I). The Amu Darya is the largest, longest and the most important river in Central Asia. The river is $2400 \mathrm{~km}$, basin area is over 500 thousands $\mathrm{km}^{2}$. Syr Darya has its most drainage areas in Kyrgyzstan, where it loses water for irrigation in its lower reaches.

With the total annual hydropower resources in the country of ca 600 billion kWh, Tajikistan is the third largest in the world and second in the new independent (post-Soviet) countries after Russia. For example, the Nurek hydroelectric power station (capacity of 3 million $\mathrm{kWh}$ ) controls about $40 \%$ of water resources needed by Uzbekistan and Turkmenistan [20]. Additionally, Tajikistan has significant fresh water reserves mostly stored in glaciers (over $60 \%$ of Central Asia).

TABLE I

FORMATION OF SYR DARYA AND AMU DARIA RIVERS IN CENTRAL ASIAN REPUBLICS [12]

\begin{tabular}{|l|c|c|c|c|c|}
\hline $\begin{array}{l}\text { Basin } \\
\text { drainage }\end{array}$ & Uzbekistan & Kyrgyzstan & Kazakhstan & Tajikistan & Iran \\
\hline Syr Daria & $15.2 \%$ & $75.2 \%$ & $6.9 \%$ & $2.7 \%$ & $0 \%$ \\
\hline $\begin{array}{l}\text { Amu } \\
\text { Daria }\end{array}$ & $13.9 \%$ & $0 \%$ & $0 \%$ & $74 \%$ & $8.5 \%$ \\
\hline
\end{tabular}

TABLE II

AREA UNDER IRRIGATION IN ARAL SEA BASIN, THOUSANDS OF HA AND \% [22]

\begin{tabular}{|l|c|c|c|c|c|c|}
\hline Year & Kazakhstan & Kyrgyzstan & Tajikistan & Turkmenistan & Uzbekistan & Total \\
\hline $\mathbf{1 9 9 0}$ & $78210.5 \%)$ & $410(5.6 \%)$ & $714(9.4 \%)$ & $1339(18.0 \%)$ & $4222(56.5 \%)$ & $7507(100 \%)$ \\
\hline $\mathbf{1 9 9 5}$ & $786(9.8 \%)$ & $416(5.2 \%)$ & $719(9.1 \%)$ & $1736(21.7 \%)$ & $4298(54.2 \%)$ & $7955(100 \%)$ \\
\hline $\mathbf{2 0 0 0}$ & $786(10.0 \%)$ & $415(6.0 \%)$ & $719(9.0 \%)$ & $1714(22.0 \%)$ & $4259(53.0 \%)$ & $8101(100 \%)$ \\
\hline
\end{tabular}


TABLE III

STRUCTURE OF ENERGY SOURCES IN CENTRAL ASIA [22]

\begin{tabular}{|c|c|c|c|c|c|}
\hline Country & Hydro energy & Gas & Oil & Coal & Total \\
\hline Tajikistan & $96 \%$ & $2 \%$ & $1 \%$ & $1 \%$ & $100 \%$ \\
\hline Kyrgyzstan & $82 \%$ & $2 \%$ & $5 \%$ & $11 \%$ & $100 \%$ \\
\hline Kazakhstan & $1 \%$ & $16 \%$ & $50 \%$ & $33 \%$ & $100 \%$ \\
\hline Uzbekistan & $1 \%$ & $84 \%$ & $13 \%$ & $2 \%$ & $100 \%$ \\
\hline Turkmenistan & $0 \%$ & $83 \%$ & $17 \%$ & $0 \%$ & $100 \%$ \\
\hline Total & $2 \%$ & $48 \%$ & $33 \%$ & $17 \%$ & $100 \%$ \\
\hline
\end{tabular}

The uneven distribution of water resources in Central Asia evidently leads to regional and local conflicts of interest among key water providers (Tajikistan and Kyrgyzstan) and its major customers (Uzbekistan, Kazakhstan and Turkmenistan). In particular, Tajikistan and Kyrgyzstan are interested to generate hydro power electricity both to meet their own needs and for export to third countries. They are opposed by Kazakhstan, Turkmenistan and Uzbekistan, which insist on the primarily irrigation water usage, for old hydro power plants built in Soviet times, as well as for the new ones planned [21].

With the total annual hydropower resources in the country of ca 600 billion $\mathrm{kWh}$, Tajikistan is the third largest in the world and second in the new independent (post-Soviet) countries after Russia. For example, the Nurek hydroelectric power station (capacity of 3 million $\mathrm{kWh}$ ) controls about $40 \%$ of water resources needed by Uzbekistan and Turkmenistan [20]. Additionally, Tajikistan has significant fresh water reserves mostly stored in glaciers (over 60\% of Central Asia).

The main point of claims from Kyrgyzstan and Tajikistan to the neighboring countries consists in financial expenses that they bear due to hydro plant exploitation. They require that Uzbekistan, Kazakhstan and Turkmenistan increase their financial contribution for Kyrgyzstan and Tajikistan. The main demand is to contribute equally to the expenses of hydroelectric power production. Kyrgyzstan and Uzbekistan debate over the years about prices to maintain hydro-technical infrastructure. Kyrgyzstan considers water as a commercial product and wants to introduce a monetary charge for water in the future (nowadays, Kyrgyzstan receives some compensation for excess in generated electricity from Uzbekistan and Kazakhstan). But the problem in the region is that price elasticity in the region is very low [4], which means that it is with difficulties that countries perform a dialog about market relationships.

In view of this, a paid water usage on the commercial basis is the worst idea to be introduced in Central Asia. Possibly it can cause high risks of social and political rebels and revolutions in the countries within the region. The official purpose of Kyrgyzstan and Tajikistan is to receive reasonable market compensation from other central Asian countries for services that they provide with water supply [12]. Though both these countries are trying to solve current financial problems by increasing state wealth, but current strategy should be adjustment into a regional scenario of sustainable geopolitical development with all countries as beneficiaries and no those one in disadvantage position. Another problem within the region consists of active water usage for agricultural needs, which is in general increasing (Table II). An additional factor of hydro energetic difficulties in the region is caused by an artificially accelerated development of hydro power energetics in Tajikistan compared to actual water usage, since the country does not have enough oil and gas reserves. Thus, as planned on the governmental level, by 2010, Tajikistan plans to become an energy independent state and start electricity export to Iran, Pakistan and India. For instance, in Tajikistan it is planned to construct 14 hydroelectric power plants on the river Panj, a major tributary of the Amu Darya, and on river Rogun (Fig.3).

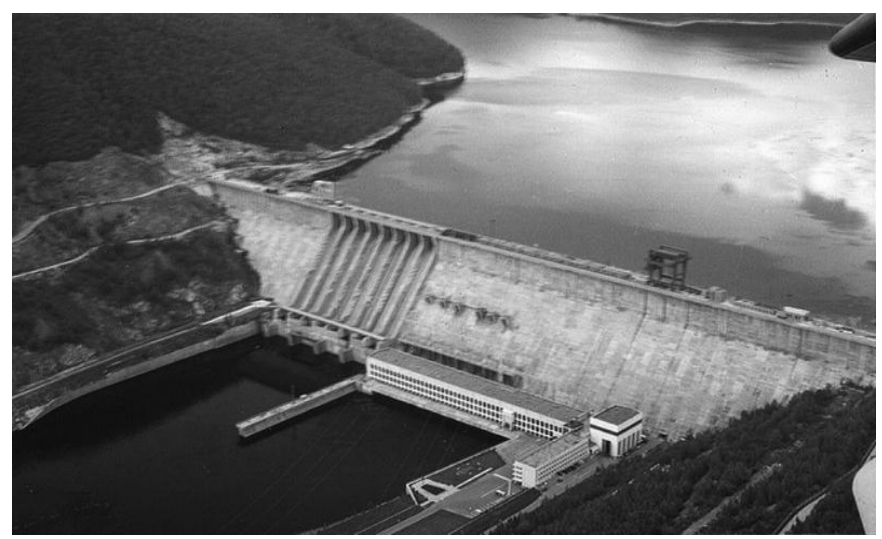

Fig. 3. The Rogun dam for planned hydro power plants of Vakhsh River (under construction), Tajikistan [23]

This project is interesting to investors from the United States,Pakistan and China. Kyrgyzstan is also seeking foreign investors for the construction of the cascade of Kambarata hydro power plants on Syr Darya. This situation caused negative reaction of neighbor countries, because construction of new hydropower plants will involve serious changes in water delivery: huge dams will be constructed and large territories will be filled out by the water (Fig.3), which will cause water shortage in the surrounding territories. Evidently, the nondiplomatic, one-sided energy policy of energy-rich countries can lead to difficulties in geopolitical relationships, especially with strategic neighboring countries.

The problem of water usage and delivery is a constant and important topic in the energy debates in Central Asia. Uzbekistan and Turkmenistan are countries with predominant natural gas economy, rich in hydrocarbon resources [16]. Kazakhstan has the most significant oil resources and natural gas reserves, and is expected to become one of the world's top 10 oil producers within the next decade [11]. Therefore, these hydrocarbon rich countries threaten to make pressure on Tajikistan and Kyrgyzstan, using resources of natural gas that they almost totally control (Table III).

Lack of water in the densely populated Ferghana valley in Uzbekistan is a serious potential trigger of social revolution, which may arise in case of deficit of water. In such situation special attention should be paid to oil and natural gas resources stored in the Caspian Sea basin, which is a potential major reservoir for energy [7].

However, consensus in the energy usage should be strongly observed for all parties, since the supply in oil, gas, hydro and 
coal resources are distributed highly unevenly in the studied region (Table III). Local Uzbek-Kyrgyz conflicts concerning water supply happen from time to time in Ferghana valley (Uzbekistan). The main claim of Uzbekistan is to provide necessary amount of water for Uzbek agriculture. However, the prices for the water resources are often a point of disagreement. The debates about new hydro plants construction arise, because it will negatively affect sensitive environment and a man-nature balance within the region. To reduce water supply conflicts, water management should be based on effective operating existing hydro power plants rather than construction of new water supply systems [9]. The effective management options and decisions for economic values should be taken in an integrated manner, so that problem of water scarcity can be smoothly resolved.

\section{CONCLUSION AND DisCUSSION}

The Central Asian region is one of the most complex regions of the world, due to the difficult geopolitical situation, complex boundaries pattern and concentration of the densely populated countries with a huge demand for water resources. At the same time, after the fall of the USSR the financial situation of Central Asian countries became difficult. Lack of development investments lead to an outdated style of economy and agrarian system (e.g. ineffective, water-consuming irrigation). The situation is aggravated by natural factors (fundamental climate issues and glacier melt).

Since the independence of Central Asian countries after the disintegration of the USSR, there were serious tensions on the point of sharing water resources. The main reason for these conflicts is caused by uneven distribution of the resources and geospatial location of the involved countries: Uzbekistan, Turkmenistan and Kazakhstan, located in the lower reaches of Tian Shan region, have lack of the resources though demand huge amount of water for various needs, while Tajikistan and Kyrgyzstan, typically mountain countries, are rich in water resources and control almost all hydro-energetic resources, supply and delivery within the region. The paradox in this situation consists in the overall availability of the water resources in the Tian Shan region. In general, there are more than enough water resources in Central Asia.

Many of the problems are caused by ineffective resource management. Thus, excessive loss of water use in Central Asia is mostly caused by an old irrigation system, which is still traditionally used in agriculture, when water consumption exceeds 3-10 times the world standards. The transition towards a modern agricultural system and sustainable water management will save considerable amounts of water resources in the region. Another problem is that the modernization of the Central Asian agriculture and introduction of modern city management require serious internal support and external financial investments.

\section{RECOMMENDATIONS}

The use of global renewable and clean energy is constantly a point of concern in the bordering countries. Nowadays, in view of increased environmental awareness, regulations on distribution of natural resources have been developed and coordinated by governmental agencies and non-commercial political organizations.

The main recommendation for the Central Asian region includes monitoring of the regulating processes in hydroenergetic resources distribution and legalized agreements among the stakeholders and participating countries. The sustainable use of energy resources and further development of the legalized regulations in the energetic industry in the neighboring states will present new perspectives of collaboration. Namely, they will create opportunities and challenges in the successful cooperation both in commercial, market and political sectors and in the environmental agencies. Opportunities should be presented in form of improved technologies of the hydroenergetic plants, systems of water treatment, distribution and delivery.

Furthermore, the optimal decision of the sustainable water usage in Central Asia, should be based on well-balanced and politically wise decisions, which consider interests of all countries. This should be taken as a major, general direction for further development of hydro energetic system in Central Asia. Thus, the decisions taken at governmental level should be well discussed and agreed by all parties, with strictly coordinated actions at local, regional and national levels of water and hydroenergy management. The decisions should be exact and concrete.

Advisable can also be involvement of the independent third governmental party with no interest in local conflict, which could assist in solving dubious questions of water energy usage and supply. Current paper performed critical analysis of the geopolitical situation caused by uneven distribution of hydro energetic resources within Central Asia, as well as discussion and an overview of some of the current local conflicts and tensions caused by ineffective management of water resources. Besides, a geospatial analysis of the current environmental problems within the study area, caused by the climatic and anthropogenic factors, is made.

Finally, the inter-governmental contradictions between the states controlling water resources and those consuming them should be regulated. This should involve reviewed legislation and international processes for sustainable regulation of the resources, as well as maintaining political interests of each participating country. The governments of the involved countries should take measures first, to establish and elaborate new ways to support existing technologies, second, to control further development and modernization of the hydro-energetic plant systems, and third, to attract new investments from the potential partners, i.e. commercial organizations.

\section{REFERENCES}

1. Aizen, V. B., Aizen, E. M., Melack, J. M., and Dozier, J.: Climate and hydrologic changes in the Tien Shan, central Asia. Journal of Climate, 10 (1997), 1393-1404. $\quad$ http://dx.doi.org/10.1175/15200442(1997)010<1393:CAHCIT>2.0.CO;2

2. Aizen, V. B., \& Aizen, E. M. Glacier Runoff Estimation and Simulation of Streamflow in the Peripheral Territory of Central Asia. Snow and Glacier Hydrology (Proceedings of the Kathmandu Symposium), 1993, IIAHS Publications, 218 
3. Aizen, V. B., Aizen E. M., \& Melack, J. M. Precipitation, melt and runoff in the northern Tien Shan. Journal of Hydrology, 186 (1996), 229-251. http://dx.doi.org/10.1016/S0022-1694(96)03022-3

4. Atakhanova, Z., and Howie, P. Electricity demand in Kazakhstan. $\begin{array}{llll}\text { Energy } & \text { Policy } & 35 & \text { (2007), }\end{array}$ http://dx.doi.org/10.1016/j.enpol.2007.01.005

5. Aus der Beck, T., Voss, F., Florke, M. Modelling the impact of Global Change on the hydrological system of the Aral Sea basin. Physics and Chemistry of the Earth 36 (2011), 684-695. http://dx.doi.org/10.1016/j.pce.2011.03.004

6. Bazhev, A. B., Kotlyakov, V. M., Rototayeva, O. V. \& Varnakova, G. M The problems of present- day glaciation of the Pamir-Alai. Snow and IceSymposium-Neiges et Glaces. In: Proceedings of the Moscow Symposium August 1971, IAHS-AISH, 104

7. Bahgat, G. Prospects for energy cooperation in the Caspian Sea Communist and Post-Communist Studies 40 (2007) 157-168. http://dx.doi.org/10.1016/j.postcomstud.2007.03.006

8. Bondarev, L. G., Gobedzhishvili, R. G. and Solomina, O. N Fluctuations of local glaciers in the southern ranges of the former USSR: 18,000-8,000 BP. PII, 1997, 1040-6182(96)00023-7.

9. Harou, J.J., Pulido-Velazquez, M., Rosenberg, D.E., Medellin-Azuara, J., Lund, J.R., and Howitt, R.E. Hydro-economic models: Concepts, design, applications, and future prospects. Journal of Hydrology 375 (2009), 627-643. http://dx.doi.org/10.1016/j.jhydrol.2009.06.037

10. Kaab, A. Climate change impacts on mountain glaciers and permafrost (Editorial). Global and Planetary Change, 56 (2007), 07-09.

11. Kaiser M.J., Pulsipher A.G. A review of the oil and gas sector in Kazakhstan. Energy Policy 35 (2007) 1300-1314. http://dx.doi.org/10.1016/j.enpol.2006.03.020

12. Kirsanov, I. Struggle for water in central Asia (in Russian). An independent observer of the GUS countries (in Russian) 12 (2006).

13. Liu, M.F.M., Pistorius, T. Coping with the energy crisis: Impact assessment and potentials of non-traditional renewable energy in rural

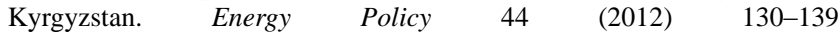
http://dx.doi.org/10.1016/j.enpol.2012.01.025

14. Normatov, I. S., Petrov, G.N. Economic question of hydro-energetic development in Tajikistan (in Russian). Dushanbe, 2007. Republican PressCenter, 1-60.

15. Olsson, O., Gassman, M., Wegerich, K., and Bauer, M. Identification of the effective water availability from streamflows in the Zerafshan river basin, Central Asia. Journal of Hydrology 390 (2010) 190-197. http://dx.doi.org/10.1016/j.jhydrol.2010.06.042

16. Saidkhodjaeva, M. Uzbekistan, an expanding and capital-hungry economy: specific inter-related opportunities in energy, IT and agriculture. Energy Policy 32 (2004), 1243-1245. http://dx.doi.org/10.1016/S0301$\underline{4215(03) 00137-X}$
17. Schluter, M., Savitsky A.G., McKinney, D.C., Lieth, H. Optimizing long-term water allocation in the Amudarya River delta: a water management model for ecological impact assessment. Environmental Modelling \& Software $20 \quad$ (2005), 529-545. http://dx.doi.org/10.1016/j.envsoft.2004.03.005

18. Singh, P., and Haritashya, U. K.: Encyclopedia of Snow, Ice and Glaciers. Springer, 1st edition, XLVI, 2011, 1-1254. http://dx.doi.org/10.1007/978-90-481-2642-2

19. Vakhidov, M. Hydropower in Tajikistan in the context of the interests of Uzbekistan. 2011. Bely Parus.

20. Wegerich, K., Olsson, O., and Froebrich, J. Reliving the past in a changed environment: Hydropower ambitions, opportunities and constraints in Tajikistan. Energy Policy 35 (2007), 3815-3825. http://dx.doi.org/10.1016/j.enpol.2007.01.024

21. Yuldasheva, G., Hashimova, U., and Callahan. Current Trends in Water Management in Central Asia. The Peace and Conflict Review 5 (1), 2012. ISSN: $1659-3995$

22. Eurasian Development Bank webpage, [Accessed: 12.08.2013] Available: http://eabr.org/e/

23. Procella webpage [Accessed: 12.08.2013] Available: http://procella.ru

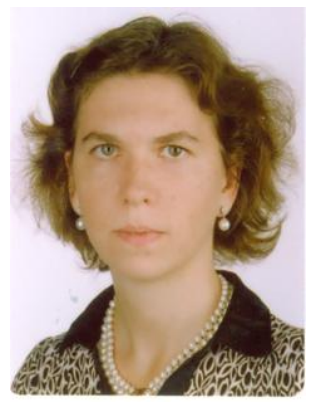

Polina Lemenkova received her BSc degree and a University Gold Medal from Moscow State Lomonosov University, Faculty of Geography (2004). She graduated with an MSc in Geo-Information Science and Earth observation from the University of Twente (Netherlands, 2011). Since 2013 she continues her education at $\mathrm{PhD}$ level at Charles University in Prague. She studies environment of mountainous landscapes in Sumava forests. A professional geographer, Polina visited over 20 countries worldwide. She actively develops her career: an author of several publications, a member of geoscience societies and active participant of conferences. Her research interests focus on geosciences, GIS mapping, remote sensing, geoinformatics and ecology. Current research was done during her research at TU Dresden, where she studied landscapes, climate change and natural resources in Tian Shan region.

Address: Zvoníčkova 1927/5, Kolej Hvězda, 3/24, 16208 Praha 6, Czech Republik

E-mail: pauline.lemenkova@gmail.com 